\title{
HUBUNGAN PENGETAHUAN IBU HAMIL TENTANG COVID-19 DENGAN PERILAKU PENCEGAHAN PENULARAN COVIT-19
}

\author{
Nurhasanah $^{1^{*}}$, Dita Alifhia Maulida ${ }^{2}$, Erawati $^{3}$ \\ STIKes Muhammadiyah Cirebon \\ *Korespondensi email khansa_noer@yahoo.com
}

\begin{abstract}
THE RELATIONSHIP OF PREGNANT WOMEN KNOWLENDE ABOUT COVID-19 WITH BEHAVIORS TO PREVENT THE COVID-19 TRANSMISSION
\end{abstract}

Background Knowledge is the basis for pregnant women to do one behavior, the presence of Covid-19 makes pregnant women have to be able to make prevention efforts, pregnancy hormones make a pregnant woman a vulnerable group for the corona virus, therefore a pregnant woman must have good knowledge so that have good behavior in the effort to prevent Covid-19.

Purposes to assess the knowledge of pregnant women about Covid-19 and the relationship between knowledge and prevention behavior.

Methods This study used a cross sectional design. The population of all pregnant women at the Arsy Media Clinic, Cirebon Regency. Sampling using Acidal sampling. The data taken are primary data obtained through a questionnaire given to 40 pregnant women. The correlation test used is Chi-Square. Research Results Most pregnant women have poor knowledge about Covid-19. All pregnant women in this study showed a positive attitude, namely by answering answers carefully, calmly and efforts to improve health. Pregnant women have bad preventive behavior against Covid-19 transmission. There is a significant relationship between knowledge and behavior of pregnant women regarding Covid-19 with a value $(p=0.000)$.

Conclusion It was found that of the 40 pregnant women respondents studied, all of them had to have a positive attitude towards Covid-19. Most respondents who have poor knowledge show bad actions regarding efforts to prevent Covid-19. methods.

Suggestion Future research is expected to be able to examine more deeply about attitudes by using better

Keywords: Knowledge, Behavior, Pregnant Women, Covid-19.

\section{ABSTRAK}

Latar Belakang Pengetahuan merupakan dasar ibu hamil melakukan salah suatu perilaku, adanya Covid19 menjadikan ibu hamil harus mampu melakukan upaya pencegahan, perubahan sistem imun yang terjadi pada kehamilan dapat membuat seorang ibu hamil menjadi kelompok rentan terpaparnya corona virus, oleh karena itu seseorang ibu hamil harus mempunyai pengetahuan yang baik agar mampunyai perilaku yang baik dalam upaya pencegahan Covid-19.

Tujuan Penelitian untuk mengetahui hubungan antara pengetahuan dengan perilaku pencegahannya.

Metode Penelitian Penelitian ini menggunakan desain cross sectional. Populasi seluruh ibu hamil di Klinik Arsy Media Kabupaten Cirebon sebesar 1.440 ibu hamil. Pengambilan sampel dengan menggunakan Acidental sampling sebanyak 40 responden. Data yang diambil merupakan data primer yang didapat melalui kuesioner yang diberikan kepada ibu hamil. Uji Korelasi yang digunakan adalah Chi-Square.

Hasil Penelitian Sebagian besar (80\%) ibu hamil mempunyai pengetahuan tidak baik mengenai Covid-19. Seluruh ibu hamil dalam penelitian ini menunjukkan sikap positif yaitu dengan menrespon jawaban hati-hati, tenang dan adanya usaha peningkatan kesehatan. Mayoritas Ibu hamil mempunyai Perilaku pencegahan yang tidak baik terhadap penularan Covid-19. Terdapat hubungan signifikan antara pengetahuan dengan perlaku ibu hamil mengenai Covid-19 dengan nilai $(p=0,000)$.

Kesimpulan Didapatkan bahwa Dari 40 responden ibu hamil yang diteliti, seluruhnya mempunyai sikap yang positif terhadap Covid-19. Sebagian besar responden yang mempunyai pengetahuan tidak baik menunjukkan tindakan yang tidak baik mengenai upaya pencegahan Covid-19.

Saran peneliti selanjutnya diharapkan dapat mengkaji lebih dalam mengenai sikap dengan menggunakan metode yang lebih baik.

Kata Kunci : Pengentahuan, Perilaku, Ibu Hamil, Covid-19 


\section{JKM (Jurnal Kebidanan Malahayati),Vol 7,No.3.Juli 2021, ISSN (Print) 2476-8944 ISSN (Online) 2579-762X, Hal 432-440}

\section{PENDAHULUAN}

World Healt Organization (WHO) China Country Office pada tanggal 31 Desember 2019 melaporkan adanya kasus klunter penemonia dengan etiologi (penyebab) yang tidak jelas di Kota Wuhan, Provinsi Hubei, China. Kasus tersebut saat ini masih terus berkembang hingga akhir tahun 2020, kemudian akhirnya diketahui etiologi dari penyakit ini adalah suatu jenis novel coronavirus, yang merupakan virus jenis baru yang sebelumnya belum pernah diidentifikasi pada manusia (Kemenkes RI, 2020).

Menurut Kemenkes RI (2020) Coronavirus merupakan virus yang ditularkan secara zoonosis (antara binatang dan manusia) dan dapat menyebabkan gejala ringan hingga gejala berat. Sebelumnya terdapat dua jenis coronavirus yang dapat menyebabkan penyakit pada manusia yaitu Middle Rast Acute Respotarory Syndrome (MERSCoV) dan Severe Acute Respotarory Syndrome (SARS-CoV). Akhirnya pada tanggal 11 Februari 2020, WHO mengumumkan nama resmi dari penyakit baru ini dengan COVID-19 (Coronavirus Disease 2019). Infeksi ini dapat menimbulkan gejala gangguan pernafasan akut seperti demam, batuk, dan sesak nafas, bahkan pada kasus yang lebih berat penyakit ini dapat menyebabkan pnemobia, sindrom pernafasan akut, gagal ginjal, bahkan kematian. Menurut Kemenres RI (2020) Gejala penyakit ini dapat muncl dalam 2-14 hari setelah terpapar virus tersebut, bahkan pada beberapa orang dapat terjangkit coronavirus dengan tanpa gejala yang berat.

Penularan penyakit ini melalui tetesan kecil (droplet) yang dikeluarkan dari saluran pernafasan pada saat seseorang batuk atau bersin. Upaya yang direkomendasikan dalam pencegahan penyebaran penyakit ini adalah dengan menerapkan etika batuk dan bersin, menggunakan masker, mencucui tangan menggunakan sabun, memasak daging dan telur hingga matang, dan menghindari kontak erat dengan seseorang yang terpapar dan atau yang memiliki gejala penyakit pernafasan (Kemenkes Rl, 2020).

Saat ini tercatat ada lebih dari 97 juta kasus Covid-19 di seluruh dunia, dengan angka kematian lebih dari 2 juta jiwa. Sedangkan di Indonesia data Satuan Tugas Penanganan Covid-19 sampai dengan 20 Januari 2021 terdapat 149.388 kasus aktif Covid-19 atau $15.9 \%$ dari total kasus terkonfirmasi. Data sampai tanggal 21 Mei 2021 jumlah kasus terkonfirmasi sebanyak 1.764 .644 kasus sampai dengan akhir tahun 2020 kejadian kasusnya masih terus berlangsung (Kemenkes RI, 2020). Oleh karena itu, pada beberapa Negara termasuk pemerintahan Indonesia malakukan pencegahan dan pengendalian infeksi coronavirus terutama pada kelompok rentan yang berisiko, salah satunya adalah ibu hamil (Qiao, 2020).

Perubahan sistem imuntas yang terjadi pada kehamilan dapat membuat ibu hamil lebih rentan terhadap gangguan kesehatan salah satunya paparan coronavirus (Nurdianto, 2020). Akan tetapi kesehatan ibu hamil juga harus dipantau untuk mendapatkan perawatan antenatal yang saat ini direkomendasikan minimal 6 kali pemeriksaan pada ibu hamil. (Kemenkes RI, 2020). Pada kehamilan trimester peratama infeksi coronavirus dapat mempengaruhi janin. Semakin dini kasus infeksi, semakin besar pula risiko mengalami keguguran (Briet, 2020). Studi pada 8549 wanita yang dialkukan oleh WHO (2020) wanita hamil dengan covid-19 lebih memungkinkan melahirkan secara premature. Beberapa penelitian dampak covet-19 pada ibu hamil berisiko mengalami keguguran, gawat janin, persalinan premature, ketuban pecah dini, dan gangguan pertumbuhan janin ( $X u, 2020)$.

Komisi Kesehatan Nasional China mengidentifikasi di 50 Rumah Sakit di Wuhan sejak Desember 2019 sampai dengan 20 Maret 2020, dari 118 kasus, 112 menunjukkan gejala (simpomatis) dan 6 kasus lainnya menunjukkan gejala asimtomatis, data dari Perkumpulan Obstetri dan Ginekologi Indonesia (POGI) dalam berita yag disampaikan kepada media pertanggal 02 Juli 2021 terdapat 536 ibu hamil terkonvirmasi Covid-19 dengan angga kematian sebesar 3\%, Sampai saat ini, informasi menganai kasus covid-19 pada ibu hamil masih terbatas, hal yang dapat dilakukan sebagai upaya untuk menghindari penularan covid19 selain menjaga jarak tertentu, mencuci tangan, dan menggunakan masker, peningkatan pengetahuan tentang covit-19 harus dimiliki oleh ibu hamil (Burhan et al, 2020; Ganing, 2020)

Pengetahuan tentang covid-19 yang dimiliki ibu hamil dapat memberikan kemampuan untuk menerima, mempertahankan, dan menngunakan infromasi yang benar, sehingga akan menimbulkan sikap sebagai respon atau reaksi yang memberikan kencenderungan untuk bertindak atau berperilaku.

Kajian penelitian mengenai pengetahuan ibu hamil yang dikaitkan dengan sikap sebagai upaya pencegahan covid-19 masih belum banyak dilakukan sedangkan tingkat kehamilan samakin meningkat menjadi dasar dari tujuan penelitian ini, sehingga masyarakat dan pelayanan kesehatan dapat mengidentifikasi pengetahuan ibu hamil dan kaitannya dengan upaya pencegahan penularam covid-19. 


\section{METODOLOGI PENELITIAN}

Penelitian ini merupakan studi observasional analitik dengan rancangan penelitian crosssectional. Populasi pada penelitian ini adalah ibu hamil sebanyak 40 orang. Teknik pengambilan sampel menggunakan accidental sampling, yaitu sampel yang bersedia dan memenuhi kriteria penelitian dilakukan secara langsung terhadap 40 ibu hamil. Pengambilan data penelitian menggunakan metode wawancara terstuktur berupa kuesioner yang gunakan pada penelitian Jesica (2020) yaitu menggunakan pertanyaan tertutup yang kaitannya dengan pengetahuan, sikap dan upaya pencegahan infeksi covid-19, dimana setiap opsi jawaban pertanyaan benar yang dipiih akan memberikan nilai 1 , sedangkan bila tidak dipilih akan diberikan nilai 0 . Setiap opsi jawaban pernyataan salah yang dipilih akan diberikan nila 0 , sedangkan bila tidak dipilih akan diberikan nilai 1 , dengan asumsi ibu hamil mengetahui bahwa penyataan tersebut merupakan pernyataan yang salah.

Perhitungan pernyataan menggunakan rumus presentase, kemudian dikategorikan menjadi dua kategori yaitu baik dan tidak baik, berdasarkan modifikasi pada penilaian menurut arikunto (2010) tingkat pengetahuan dikategorikan 'baik apabila nilai yang diperoleh $>75 \%$, dan dikategorikan 'tidak baik' apabila nilai yang diperoleh $\leq 75 \%$. Sedangkan pengukuran sikap dikategorikan menjadi dua kategori yaitu 'sikap positif dan sikap negatif', sikap positif apabila ibu hamil. Sikap positif apabila ibu hamil memiliki respon tenang, berhati-hati, dan meningkatkan usaha menjaga kesehatan. Upaya pencegahan dikategorikan menjadi dua yaitu 'baik dan tidak baik'. Upaya baik apabila ibu hamil melakukan usaha berupa mencuci tangan menggunakan air dan sabun, menggunakan masker ketika keluar rumah/batuk/pilek, menjaga jarak aman.

Data kemudian dioleh menggunakan SPSS dan dianalisis secara univariat (distribusi frekuensi) dan bivariat dengan uji hipotesis Chi-square dengan tingat kemaknaan alpha=0,05 (Cl-95\%)

\section{HASIL DAN PEMBAHASAN}

Berdasarkan tabel 1, karakteristik ibu hamil meliputi usia, paritas, pendidikan, pekerjaan, latar belakang pendidikan/pekerjaan dan informasi tentang covid-19. Usia responden berkisar pada usia <20 sampai dengan 35 tahun dengan dengan usia terbanyak yaitu 20-35 tahun. Dari 40 responden mayoritas multigravida, lebih dari $22 \%$ ibu hamil memiliki kualifikasi pendidikan SMA dan bekerja sebagian besar menjadi ibu rumah tanggal $(82,5 \%)$, adapun latarbelakang pendidikan/pekerjaan seluruh ibu hamil berasal dari non kesehatan dan informasi tentang covid-19 paling banyak didapatkan dari Televisi

Tabel 1.

Karakteristik responden ( $\mathrm{N}=40)$

\begin{tabular}{|c|c|c|}
\hline Karakteristik & Jumlah & Presentase (\%) \\
\hline \multicolumn{3}{|l|}{ Usia ( Tahun) } \\
\hline$<20$ Tahun & 2 & 5 \\
\hline 21 - 35 Tahun & 28 & 70 \\
\hline > 35 Tahun & 10 & 25 \\
\hline \multicolumn{3}{|l|}{ Paritas } \\
\hline Primigravida & 8 & 20 \\
\hline Multigravida & 27 & 67,5 \\
\hline Grande multigravida & 5 & 12,5 \\
\hline \multicolumn{3}{|l|}{ Pendidikan } \\
\hline Tidak Sekolah & 0 & 0 \\
\hline SD atau sederajat & 9 & 22,5 \\
\hline SMP atau sederajat & 8 & 20 \\
\hline SMA atau sederajat & 16 & 40 \\
\hline Perguruan Tinggi & 7 & 17,5 \\
\hline \multicolumn{3}{|l|}{ Pekerjaan } \\
\hline Ibu Rumah Tangga & 33 & 82,5 \\
\hline PNS & 4 & 10 \\
\hline Pegawai Swasta & 1 & 2,5 \\
\hline Lainnya & 2 & 5 \\
\hline
\end{tabular}


JKM (Jurnal Kebidanan Malahayati),Vol 7,No.3.Juli 2021,

ISSN (Print) 2476-8944 ISSN (Online) 2579-762X, Hal 432-440

Latar Belakang Pendidikan/Pekerjaan

Kesehatan

Non-Kesehatan

$0 \quad 0$

Informasi tentang Covid-19

Televisi

$40 \quad 100$

Situs berita online

$27 \quad 67,5$

Media sosial

$4 \quad 10$

Youtube

$9 \quad 22,5$

lainnya

$0 \quad 0$

$\begin{array}{lll}\text { Total } & 40 & 100,0\end{array}$

Tabel 2.

Pengetahuan Ibu Hamil tentang Covid-19 ( $\mathrm{N}=40)$

\begin{tabular}{|c|c|c|}
\hline Komponen Pertanyaan & $\begin{array}{l}\text { Jumlah } \\
\text { (orang) }\end{array}$ & $\begin{array}{c}\text { Presentase } \\
(\%)\end{array}$ \\
\hline \multicolumn{3}{|l|}{ Apa Coronavirus itu? } \\
\hline Virus yang menyebabkan penyakit saluran pernafasan & 37 & 92,5 \\
\hline Virus yang diduga berasal dari pasar makanan laut Huanan & 3 & 7,5 \\
\hline Virus yang tidak sengaja bocor dari laboratorium senja abiologis China & 3 & 7,5 \\
\hline Virus yang sengaja disebarkan untuk memusnahkan suatu kelompok & 0 & 0 \\
\hline \multicolumn{3}{|l|}{ Apa saja gejala penyakit infeksi Coronavirus? } \\
\hline Demam & 40 & 100 \\
\hline Batuk & 27 & 67,5 \\
\hline Mimisan & 26 & 65 \\
\hline Susah bernafas & 19 & 47,5 \\
\hline Bercak merah ditubuh & 4 & 10 \\
\hline \multicolumn{3}{|l|}{ Bagaimana penularan Corona virus? } \\
\hline Menular antar manusia lewat batuk dan bersin & 38 & 95 \\
\hline Menular dari hewan kemanusia & 0 & 0 \\
\hline Menular lewat ponsel Xiaomi yang dibuat di China & 0 & 0 \\
\hline Menular lewat pandangan mata & 0 & 0 \\
\hline Menular melalui sinyal telepon & 0 & 0 \\
\hline Menular lewat bawang impor dari China & 2 & 5 \\
\hline Menular melalui kurma karena mengandung virus yang berasal dari kelelawar & 2 & 5 \\
\hline \multicolumn{3}{|l|}{ Faktor manakah yang menjadikan seseorang berisiko terinfeksi Corona virus? } \\
\hline Memiliki riwayat kontak dengan ayam, burung, dan hewan ungags lainnya & 38 & 85 \\
\hline Riwayat perjalanan ke wilayah yang terjangkit dlam waktu 14 hari sebelum timbul gejala & 28 & 70 \\
\hline Memiliki riwayat kontak erat dengan orang yang terkena infeksi ini & 12 & 30 \\
\hline Memiliki riwayat bekerja atau mengunjungi fasilitas kesehatan yang berhubungan dengan & 6 & 15 \\
\hline pasien infeksi ini Memiliki riwayat perjalanan ke Wuhan dan memiliki demam. & 0 & 0 \\
\hline \multicolumn{3}{|l|}{ Apa yang anda ketahui tentang penyembuhan infeksi Corona virus? } \\
\hline Belum ada obat spesifik untuk penyakit ini & 37 & 92,5 \\
\hline Tidak ada orang yang sembuh dari penyakit ini & 19 & 47,5 \\
\hline Air rebusan bawang putih dapat mengobati penyakit ini & 8 & 20 \\
\hline Penyakit ini bisa sembuh dengan sendirinya & 3 & 7,5 \\
\hline Dapat langsung sembuh setelah minum bodrex 5 menit & 2 & 5 \\
\hline \multicolumn{3}{|l|}{ Apa saja hal yang dapat dilakukan untuk mencegah infeksi Corona virus? } \\
\hline Menghindari berpergian ke wilayah yang angka kejadiannya tinggi & 35 & 87,5 \\
\hline Menghindari kontak langsung terhadap orang penderita & 25 & 62,5 \\
\hline Mencuci tangan menggunakan air dan sabun & 21 & 52,5 \\
\hline Memakan daging hewan setengah masak & 21 & 52,5 \\
\hline Menggunakan masker ketika berpergian keluar rumah atau saat ada gejala sakit & 15 & 37,5 \\
\hline $\begin{array}{l}\text { Menutup mulut dan hidung dengan tissue ketika bersin atau batuk } \\
\text { Apa bahaya dari infeksi Corona virus? }\end{array}$ & 10 & 25 \\
\hline $\begin{array}{l}\text { Dapat menyebabkan infeksi saluran nafas yang berat pada orang usia lanjut dan } \\
\text { gangauan sistem kekebalantubuh }\end{array}$ & 35 & 87,5 \\
\hline
\end{tabular}


Dapat memperberat kondisi seseorang yang sedang menderita penyakit tertentu

Semua pasien dengan infeksi ini mengalami gagal nafas dan meninggal

Penyakit ini tidak dapat disembuhkan

Bagiamana etika saat batuk dan bersin yang benar?

Menggunakan masker ketika sedang flu atau batuk

Setelah menggunakan tissue, tissue langsung dibuang ke kotak sampah

Mencuci tangan dengan menggunakan air bersih dan sabun atau pencucui tangan

berbasis alcohol setelah memegang tissue setelah batuk/bersin

Menutup hidung dan mulut dengan telapak tangan

Bagaimana penggunaan masker yang benar?

Masker dipakai dengan posisi menutupi hidung, mulut, dan dagu secara sempurna

Menggunakan satu masker sekali pakai untuk berulang kali

Menyentuh permukaan depan masker saat sedang menggunakannya dan saat akan melepaskannya

Jika masker basah atau kotor, harus segera diganti

Buang masker yang telah digunakan

Melakukan cuci tangan setelah membuka masker

Bagaimana mencuci tangan yang benar?

Setelah mencuci tangan, tangan dikeringkan dengan handuk atau kertas sekali pakai

Dilakukan secara rutin, terutama sebelum memegang mulut, hidung dan mata

Hanya dilakukan ketika tangan terlihat kotor saja

Saat tidak ada fasilitas cuci tangan, dapat menggunakan cairan berbasis alcohol

Menggunakan wadah cuci tangan bersama orang lain Melakukan cuci tangan dengan air mengalir dan sabun setidaknya 20 detik

$7 \quad 17,5$

Ket : Opsi jawaban yang dicetak miring adalah opsi jawaban benar. Opsi jawaban yang ditampilkan pada tabel disusun secara beruruan berdasarkan jawaban terbanyak yang dipilih oleh responden

Tabel 3.

Distribusi Ibu hamil berdasarkan Pengetahuan, Sikap, dan Perilaku ( $N=40$ )

\begin{tabular}{|c|c|c|}
\hline Variabel & Jumlah & Presentase (\%) \\
\hline \multicolumn{3}{|l|}{ Pengetahuan } \\
\hline Baik & 8 & 20 \\
\hline Tidak Baik & 32 & 80 \\
\hline \multicolumn{3}{|l|}{ Sikap } \\
\hline Positif & 40 & 100 \\
\hline Negatif & 0 & 0 \\
\hline \multicolumn{3}{|l|}{ Tindakan } \\
\hline Baik & 12 & 30 \\
\hline Tidak baik & 28 & 70 \\
\hline Total & 40 & 100 \\
\hline
\end{tabular}

Tabel 4.

HubunganPengetahuan Ibu hamil dengan Perilaku ( $\mathrm{N}=40)$

\begin{tabular}{|c|c|c|c|c|c|c|c|c|}
\hline \multirow{3}{*}{ Pengetahuan } & \multicolumn{4}{|c|}{ Perilaku } & \multicolumn{2}{|c|}{ Total } & \multirow{3}{*}{ PR Cl 95\% } & \multirow{3}{*}{$p$} \\
\hline & \multicolumn{2}{|c|}{ Baik } & \multicolumn{2}{|c|}{ Tidak Baik } & & & & \\
\hline & $n$ & $\%$ & $\mathrm{n}$ & $\%$ & $\mathrm{~N}$ & $\%$ & & \\
\hline Baik & 8 & 20 & 0 & 0 & 8 & 20 & & 0000 \\
\hline Tidak Baik & 4 & 10 & 28 & 70 & 32 & 80 & & 0,000 \\
\hline Jumlah & 12 & 30 & 28 & 70 & 40 & 100 & & \\
\hline
\end{tabular}




\section{JKM (Jurnal Kebidanan Malahayati),Vol 7,No.3.Juli 2021, ISSN (Print) 2476-8944 ISSN (Online) 2579-762X, Hal 432-440}

Berdasarkan tabel 4, sebanyak $70 \%$ responden yang berpengetahuan tidak mempunyai pengetahuan tidak baik mempunyai tindakan tidak baik mengenai Covid-19. Dari hasil uji statistic menunjukkan terdapat hubungan yang signifikan antara pengetahuan dan perilaku seseorang mengenai Covid-19 ( $p=0,000<0,05)$. Ibu hamil dengan pengetahuan tidak baik mempunyai risiko untuk memiliki tindakan yang tidak baik pula.

\section{PEMBAHASAN}

Berdasarkan tabel 1, karakteristik ibu hamil meliputi usia, paritas, pendidikan, pekerjaan, latar belakang pendidikan/pekerjaan dan informasi tentang covid-19. Usia responden berkisar pada usia <20 sampai dengan 35 tahun dengan dengan usia terbanyak yaitu 20-35 tahun. Dari 40 responden mayoritas multigravida, lebih dari $22 \%$ ibu hamil memiliki kualifikasi pendidikan SMA dan bekerja sebagian besar menjadi ibu rumah tanggal $(82,5 \%)$, adapun latarbelakang pendidikan/pekerjaan seluruh ibu hamil berasal dari non kesehatan dan informasi tentang covid-19 paling banyak didapatkan dari Televisi

Karakteristik ini sesuai dengan metode pengambilan yang dilakukan melalui wawancara langsung dengan instrument kuesioner. Berdasarkan rentang usia produktif perempuan yaitu dari 20 sampai dengan 35 tahun, hal ini menggambarkan bahwa sebagian besar sudah mendapatkan pengalaman dari kehamilan sebelumnya sehingga untuk adaptasi kehamilan lebih dipahami oleh ibu, hal ini menjadikan perhatian untuk upaya-upaya pencegahan terhadap suatu bahaya kehamilan bisa dilakukan sedini mungkin.

Dengan latar belakang pendidikan terbanyak yaitu SMA, pekarjaan sebagai ibu rumah tangga, dan latar belakang dari non kesehatan hal ini dapat memberikan gambaran kesesuaian dengan waktu luang dalam mendapatkan informasi yang berasal dari media televisi.

Analisis terhadap 40 bu hamil menunjukkan pengetahuan yang tidak baik terhadap informasi Covid-19 hingga $80 \%$, 100\% sikap ibu hamil terhadap Covid-19 menunjukkan sikap positif, dan $70 \%$ ibu hamil memiliki tindakan pencegahan tidak baik terhadap Covid-19.

Dari pertanyaan menyenai definisi Covid-19 sebagain besar ibu hamil mengetahui bahwa virus ini menyebabkan penyakit saluran pennafasan $(92,5 \%)$ da nada beberapa yang menjawab bahwa virus ini berasal dari pasar makanan laut di Huanan, namun masih ada ibu hamil yang menjawab virus ini tidak senagaj bocor dari laboratorium senjata biologis di China (7,5\%).

Seluruh responden sudah mengetahui bahwa gejala penyakit Covit-19 ibi berupa demam $(100 \%)$, batuk $(67,5 \%)$ dan Sesak nafas $(47,5)$. Walaupun masih terdapat ibu hamil sebanyak $(65 \%)$ menjawab mimisan dan $(10 \%)$ menjawab bercak merah ditubuh. Menurut Sahin (2020) berdasarkan penelitiannya menjelaskan bahwa dari 41 pasien yang dirawat mempunyai gejala paling banyak adalah demam, batuk kering, myalgia, dan fatigue, dan gejala yang ditemukan dengan jumlah sedikit adalah batuk berdahak, sakit kepala, batuk berdarah dan diare.

Hampir secara keseluruhan (95\%) responden sudah mengetahui penyebab penularan Covid-19 yaitu Menular antar manusia lewat batuk dan bersin. Namun beberapa responden masih salah mengenai informasi bahwa bawang impor dari China $(5 \%)$ dan kurma karena mengandung virus yang berasal dari kelelawar $(5 \%)$ masih dapat menyebabkan penularan, hal ini memberikan informasi bahwa masih terdapatnya berita-berita yang kurang benar terkait penularan voruc Covid19.

Dalam pertanyaan tentang Faktor manakah yang menjadikan seseorang berisiko terinfeksi Corona virus, mayoritas responden menjawab

Memiliki riwayat kontak dengan ayam, burung, dan hewan ungas (85\%) dan dilanjutkan dengan Riwayat perjalanan ke wilayah yang terjangkit dlam waktu 14 hari sebelum timbul gejala $(70 \%)$ dan Memiliki riwayat kontak erat dengan orang yang terkena infeksi ini (30) hal ini memberikan asumsi bahwa masih terdapat banyak ibu hamil yang belum mengetahu tentang riwayat perjalanan covid-19 ini.

Hamplr seluruh ibu hamil mengetahui bahwa Belum ada obat spesifik untuk penyakit ini $(92,5 \%)$ dan menyakini bahwa Tidak ada orang yang sembuh dari penyakit ini $(47,5 \%)$, hal ini menjelaskan bahwa ibu hamil belum terpapar mengenai informasi vaksin sebagai bentuk pencegahan penularan covid-19 pada masa kehamilan. Sebagai upaya pencegahan yang lain responden menjelaskan bahwa Menghindari berpergian ke wilayah yang angka kejadiannya tinggi, Menghindari kontak langsung terhadap orang penderita, dan Mencuci tangan menggunakan air dan sabun

Merupakan tindakan pencegahan terhadap Covid-19. Bahaya Covid-19 hampir seluruh responden mengetahuinya dengan menjawab Dapat menyebabkan infeksi saluran nafas yang berat pada orang usia lanjut dan gangguan sistem 


\section{Nurhasanah, Dita Alifhia Maulida, Erawati}

kekebalan tubuh $(87,5 \%)$ dan Dapat memperberat kondisi seseorang yang sedang menderita penyakit tertentu (20\%). Hal ini memberikan gambaran bahwa ibu hamil termasuk kedalam kelompok rentan terpaparnya Covid-19 karena sistem kekebalan ibu hamil yang tidak stabil diakibatkan perubahan hormone pada kehamilan.

Walaupun responden menjawab Menggunakan masker ketika sedang flu atau batuk $(75 \%)$ namun masih ada ibu hamil yang Menutup hidung dan mulut dengan telapak tangan ketika batuk dan bersin $(17,5 \%)$, dengan demikian masih ada ibu hamil yang tidak melakukan etika batuk dan bersin dengan benar. Ibu hamil sebagaian besar mengetahui cara menggunakan masker yang bernar yaitu menutupi hidung, mulut, dan dagu secara sempurna (95\%) namun masih banyak ibu hamil yang Menggunakan satu masker sekali pakai untuk berulang kali $(87,5 \%)$.

Sebanyak (47,5\%) masih ada ibu hamil yang melakukan cuci tangan jika tanganya terlihat kotor, walaupaun terdapat (85\%) Setelah mencuci tangan, tangan dikeringkan dengan handuk atau kertas sekali pakai. Dilakukan secara rutin, terutama sebelum memegang mulut, hidung dan mata $(52,5)$.

Berdasarkan pemaparan hasil penelitian diatas, masih terdapat beberapa informasi pengetahuan yang beragam mengenai Covid-19 pada ibu hamil yang memeriksakan kehamilannya di Klinik Pratama Arsy Medika Kabupaten Cirebon. Beberapa penelitian yang dilakukan pada ibu hamil mengenai covid-19 pada ibu hamil belum banyak dilkukan dengan skala besar sehingga hasil penelitian pengetahuan masih beragam, hal ini dapat dipengaruhi beberapa aspek yaitu kecemasan (Amalina, 2021) dan pendampingan dari tenaga kesehatan atau kader kesehatan pada ibu hamil (Riana, 2021) sehingga dapat meningkatkan pengetahuan dan pemahaman mengenai covid-19 secara aktual. Hal lain dikemukakan oleh (Sulistyaningtyas, 2020) bahwa Pengetahuan yang baik dapat didukung oleh penerimaan terhadap informasi yang beredar di masyarakat tentang Covid-19.

Pada penelitian sebelumnya (Jesica,2020) yang dilakukan kepada masyarakat Indonesia dengan pengambilan data secara daring didapatkannya hubungan antara pengetahuan dan tindakan seseorang, hal ini juga sesuai dengan teori yang dipaparkan oleh Notoatmodjo (2014) bahwa pengetahuan dipengaruhi oleh pengalaman seseorang dan lingkungan yang kemudian diekspresikan dan diyakini sehingga menimbulkan motivasi. Dari responden yang seluruhnya adalah ibu hamil beratar belakang non kesehatan, kualifikasi pendidikan SMA dan memiliki pekerjaan sebagai ibu rumah tangga dapat mempengaruhi pengetahuan terhadap Covid-19, hal ini dapat diasumsikan bahwa dari hasil penelitian dapat sejalas dengan teori tersebut.

Berdasarkan tabel 4, sebanyak $70 \%$ responden yang berpengetahuan tidak mempunyai pengetahuan tidak baik mempunyai tindakan tidak baik mengenai Covid-19. Dari hasil uji statistic menunjukkan terdapat hubungan yang signifikan antara pengetahuan dan perilaku seseorang mengenai Covid-19 ( $p=0,000<0,05)$. Ibu hamil dengan pengetahuan tidak baik mempunyai risiko untuk memiliki tindakan yang tidak baik pula.

Seluruh ibu hamil dalam penelitian ini menunjukkan sikap positif yaitu dengan menrespon jawaban hati-hati, tenang dan adanya usaha peningkatan kesehatan. Hal ini bertolak belakang dari penelitian sebelumnya bahwa pengetahuan dapat berhubungan dengan sikap (Jesica, 2020) dan juga pada penelitian yang dilakukan Zhong (2020) pada masyarakat China yang membuktikan bahwa terdapat hubungan pengetahuan dengan sikap positif terhadap Covid-19. Hal ini memberikan gambaran bahwa komponen sikap harus lebih dapat dikaji kembali pada penelitian selanjutnya, apakah dengan menggunakan metode wawancara mendalam atau sebagainya.

Penilaian komponen tindakan dalam penelitian ini memberikan penjelasan bahwa sebagain besar ibu hamil masih memiliki tindakan pencegahan yang tidak baik $(70 \%)$.

Hal ini sejalan dengan teori dari Notoatmodjo bahwa pengetahuan merupakan suatu domain kognitif yang sangat mempengaruhi seseorang damam membentuk suatau tindakan. Dan menurut (Silalahi, 2013) menjelaskan bahwa perilaku seseorang tidak akan bertahan lama tanpa didasarkan oleh pengetahuan. Menurut Nur Eliyun (2021) untuk menghindari penyebaran virus Covid19 keoada ibu hamil, perilaku yang harus dilakukan secepatnya adalah dengan meningkatkan pengatahuan mengenai protokol kesehatan.

\section{SIMPULAN}

Dari 40 responden ibu hamil yang diteliti, luruhnya mempunyai sikap yang positif terhadap Covid-19, yaitu menunjukkan sikap hati-hati dan tenang serta mempunyai upaya peningkatan kesehatan. Sebagian besar responden yang mempunyai pengetahuan tidak baik menunjukkan tindakan yang tidak baik mengenai upaya pencegahan Covid-19. 


\section{JKM (Jurnal Kebidanan Malahayati),Vol 7,No.3.Juli 2021, ISSN (Print) 2476-8944 ISSN (Online) 2579-762X, Hal 432-440}

\section{SARAN}

Penelitian selanjutnya diharapkan dapat mengkaji lebih dalam mengenai sikap dengan menggunakan metode yang lebih baik.

\section{DAFTAR PUSTAKA}

Arikunto, S. 2010. Prosedur Penelitian : Suatu Pendekatan Praktik. Jakarta : Rineka Cipta. Cet. Ke-13

Aritonang, J., Nugraeny L (2020). Peningkatan pemahaman kesehatan pada ibu hamil dalam upaya pencegahan Covid-19. Jurnal Solma Vol 09, No.2,

Briet, $E$ (2020). Is termination of early pregnancy indicated in women with Covid-19. Journal of Obstetrics \& Gynocology and Reproductive Biology, 251:266284

Burhan, E., Isbaniah, F., Susanto, AD., et al. (2020). Pnemonia covid-19 Diagnosis \&Penatalaksnaan Di Indonesia Vol 55. Doi:10.1331/JAPhA.2015.14093

Kamus Besar Bahasa Indonesia (2014), https:kbbi.kemendikbud.go.id

Kemenkes RI. (2020). Pedoman Bagi lbu hamil dan Ibu nifas Selama Social Distancing. Jakarta: Kemenkes RI

Kemenkes RI. (2020). Pedoman Pencegahan dan pengendalian Coronavirus Disease (Covid19). Jakarta: Kemenkes RI. 0-115

Kemenkes RI (2020), Cuci tangan Bunuh Virus Covid-19, Dlpublikasikan 07 Mei 2020

Kemenkes RI (2020), Pedoman Pelayanan Antenatal, Persalinan, Nifas, dan Bayi Baru Lahir di Era Adaptasi Kebiasaan Baru. Jakarta : Kemenkes RI 0-73

Jesika Moudy (2020). Pengetahuan terkait Usaha Pencegahan Coronavirus Disease (COVID19) di Indonesia. HIGEIA Journal Of Public Health Research and Development

Syakurah, R. and Moudy, J. (2020) "Pengetahuan terkait Usaha Pencegahan Coronavirus Disease (COVID-19) di Indonesia", HIGEIA (Journal of Public Health Research and Development), 4(3), pp. 333-346. doi: 10.15294/higeia.v4i3.37844.

Perkumpulan Obstetri dan Ginekologi Indonesia (2020). Rekomendasi Penanganan Infeksi Virus Corona (Covid-19) pada Maternal (Hamil, Bersalin dan Nifas). POKJA Infeksi Saluran Reproduksi.

World Health Organization. (2020) Naming the coronavirus disease (Covid-19) and the virus that causes it. 2020.
World Health Organization. (2020) Corona Virus disease (Covid-19) Situation Report-114, May 13, 2020

Notoadmodjo. 2003. Metodologi Penelitian Kesehatan. Jakarta: Rineka Cipta.

Notoadmodjo. 2014. Pendidikan Dan Perilaku Kesehatan. Jakarta: PT Renika Cipta.

Nur Eliyun (2021) Literatur Review Upaya Pencegahan Covid-19 Pada lbu Hamil, diakses melalui https://publikasiilmiah.ums.ac.id/handle/1161 $7 / 12415$

Nursalam \& Pariani. 2001. Pendekatan Praktik Metodologi Penelitian Keperawatan. Jakarta: Cv. Agung Setio.

Nursalam. 2003. Konsep Dan Penerapa Metodologi Penelitian IIm Keperawatan Jakarta: Salemba Medika.

Rahmat, Jalaluddin. 2009. Psikologi Komunikasi. Bandung : remaja rosdakarya

Sistiarni, C (2014). Fungsi Pemanfaatan Buku Kesehatan Ibu dan Anak pada Ibu. Jurnal Kesehatan Masyarakat Nasional, Vol 8 No 8.

Sahin, A.R.,Erdogan, A.,Agaoglu, P.M.,Dineri,Y.,Cakirci,A.Y (2020) Novel Coronavirus (COVID-19) Outbreak : A Roview of the Current Literature. EJMO, $4(1): 1-7$

Silalahi, C.,Lampus, B., Akili, R., Sam, U., Manado, R. 2013. Hubungan antara pengetahuan dan sikap perawat tentang HIV / AIDS dengan tindakan perawat terhadap penederita HIV I AIDS di Rumah Sakit Pancaran Kasih Manado. Media Kesehatan FKM UNSRAT, 46:1-5

Sulistyaningtyas Tri (2020), Informasi Wabah Virus Covid-19 : Kuasa Pengetahuan dan Kelas Sosial.

Riana, E.,Susanti, T.,Ananda, N.R., \& Anisa, R. (2021) Pendampingan lbu Hamil di era Pandemi Covid-19 dalam upaya peningkatan cakupan pelayanan ibu hamil di Puskesmas Karya Mulya Pontianak, Selaparang Jurnal Pengabdian Masyarakat Berkemajuan, $4(2), 122-126$

Amalina, R.N (2021) Hubungan Tingkat pengetahuan tentang Covid-19 dengan Tingkat Kesecamasan pada Ibu hamil saat pandemic Covid-19 di Wilayah Kerja Puskesmas Purwokerto Selatan (Doctoral dissertation, Universitas Jenderal Soedirman)

Zhong, B.L., Luo, W. Li H.M., Zhang, Q. Liu, X. G (2020) Knowlehde, Attitudes, and practices towards Covid-19 among Chinese residents 


\section{Nurhasanah, Dita Alifhia Maulida, Erawati}

during the rapid rise period of tha Covid-19 outbreak : a quick online cross-sectional survey. Int J Biol Sci, 160 (10):1745-52.

CNN Indonesia, POGI : 536 lbu Hamil Positif Covid, 3 Persen Meninggal, dipublikasikan 02 Juli 2021 jam $13.51 \quad$ wib https://www.cnnindonesia.com/nasional/2021 0702133914-20-662272/pogi-536-ibu-hamilpositif-covid-3-persen-meninggal

Qiao, J. (2020). What are the risks of Covid-19 infection in pregnant women? The Lancet, $395,760-762$

Xu Qiancheng, S.J. (2020). Coronavirus disease 2019 in pregnancy. International Journal of Infectious Diseases, 95 (2020), 376-383. 